\title{
Ege Üniversitesi hastanesi veri tabanında kayıtlı erişkin akut lösemi olgularının epidemiyolojik ve genel sağkalım özelliklerinin retrospektif olarak değerlendirilmesi
}

\author{
Retrospective evaluation of the epidemiological and overall survival characteristics of \\ adult acute leukemia cases registered in the database of Ege University hospital

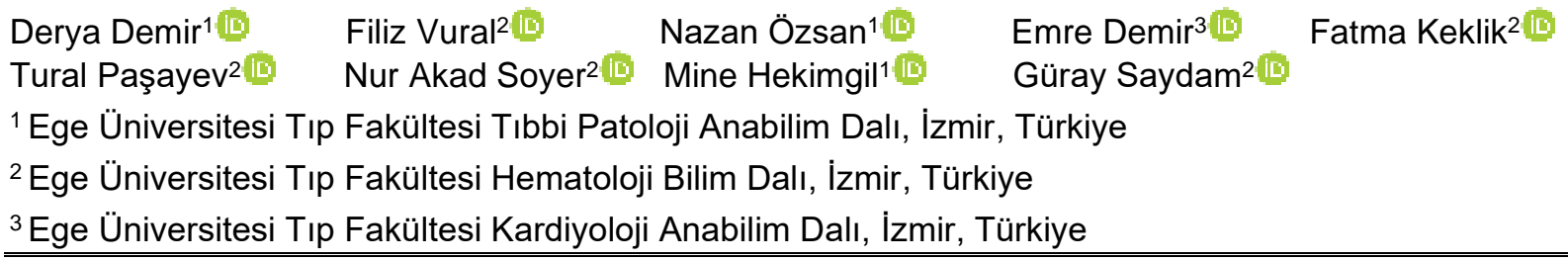

Öz

Amaç: Akut lösemi/lenfoma ve myeloid sarkom, hematopoietik prekürsör hücrelerden gelişen klonal neoplastik proliferasyonlardır. Bu çalışmada, olgularının epidemiyolojik analizlerinin yapılması, global sonuçlarla karşılaştırılarak değerlendirilmesi amaçlanmıştır.

Gereç ve Yöntem: Ege Üniversitesi Kanserle Savaş Araştırma ve Uygulama Merkezi veri tabanına kayıtlı, 1992-2017 yıllarında akut lösemi/lenfoma ve myeloid sarkom tanısı alan 2.046 erişkin olgu retrospektif olarak değerlendirilmiştir.

Bulgular: Olguların \%58'i erkek olup; ortalama tanı yaşı 50,62, medyan tanı yaşı ise 52 idi. En sık $(\% 62,5)$ akut myeloid lösemi (AML) izlendi. Olguların \%95,8'i lösemik prezentasyon göstermekteydi. Sınıflandırılamayan lenfoblastik lösemi (ALL) olguları yıllara göre azalırken, diğer gruplarda yıllara göre lösemi tanısında artış dikkatimizi çekti. Çocukluk yaş grubunda daha sık karşımıza çıkan ALL olgularında yaş arttıkça görülme oranlarının azaldığı, hücre dizisi belirsiz akut lösemi olgularında ise yaş arttıkça görülme oranlarının da arttığı saptandı. AML ve tüm lösemi olguları ise en çok 40-64 yaş aralığında yer almaktaydı. Akut lösemi olgularında 1, 5, 10 ve 25 yıllık sağkalım sırasıyla \%55,7, \%29, $\% 23$ ve \%15 olarak bulundu. Ayrıca sağkalım 18-39 yaş grubunda $\% 52,3,40-64$ yaş grubunda $\% 35,3$, 65 yaş ve üstü grupta $\% 20,9$ idi.

Sonuç: Cinsiyet ve sağkalım arasında bir fark saptanmaz iken, lösemik prezentasyon gösterenlerde, tedavi almayan olgularda ve yaş arttıkça sağkalım daha kısa bulunmuş ve istatistiksel olarak da anlamlı saptanmıştır. Prognozda, histolojik tip, yaş ve tedavi bizim çalışmamızda da öne çıkan önemli parametrelerdendir.

Anahtar Sözcükler: Lösemi, myeloid sarkom, epidemiyoloji, insidans, sağkalım.

\begin{abstract}
Aim: Acute leukemia/lymphoma and myeloid sarcoma originated from hematopoietic precursor cells are clonal neoplastic proliferations. The aim of this study was to evaluate the epidemiological analysis of patients and compare them to global findings.

Materials and Methods: The data, including 2,046 adult patients diagnosed as acute leukemia/lymphoma, and myeloid sarcoma recorded at Ege University Cancer Control and Research Center, within 1992-2017, were evaluated retrospectively.
\end{abstract}

\footnotetext{
Sorumlu yazar: Derya Demir

Ege Üniversitesi Tıp Fakültesi Tıbbi Patoloji Anabilim Dalı,

İzmir, Türkiye

E-posta:dr.derya.demir@gmail.com
} 
Results: Of the patients, $58 \%$ was male; the mean age was 50.62, the median age was 52. The most common type of leukemia (62.5\%) was acute myeloid leukemia (AML). Leukemic presentation was seen in $95.8 \%$ of the patients. While the non-specified type of lymphoblastic leukemia (ALL) decreased in years, the diagnosis of leukemia in other groups increased in years. It was found that the incidence of ALL, which are more common in the pediatric age, decreased with age, and the incidence of acute leukemia with ambiguous lineage increased with age. Most of the AML and all leukemia patients were in the age range of 40-64. Overall survival for 1, 5, 10, and 25-year in patients with acute leukemia were $55.7 \%, 29 \%, 23 \%$, and 15\%, respectively. In addition, it was 52.3\% in the 18-39 age range, $35.3 \%$ in the $40-64$ age range, and $20.9 \%$ in the 65 age and over.

Conclusion: While there was no significant difference between gender and survival, leukemic presentation, untreatment and older age was statistically significantly correlated with poor overall survival. Histologic type, age, and treatment of the disease were found to be among the most important prognostic parameters in our study

Keywords: Leukemia, myeloid sarcoma, epidemiology, incidence, survival.

\section{Giriş}

Hematopoietik prekürsör hücrelerden gelişen klonal neoplastik proliferasyonlar akut myeloid lösemi (AML), B lenfoblastik lösemi/lenfoma (B$A L L / B-L B L)$ ve $T$ lenfoblastik lösemi/lenfoma ( $T$ ALL/T-LBL), myeloid sarkom ve hücre dizisi belirsiz akut lösemiler olmak üzere başlıca gruplara ayrılır (1).

AML erişkinlerde en sık görülen lösemi tipidir. 2018 yılında Amerika Birleşik Devleti'nde (ABD) 19.520 yeni $A M L$ olgusu ve 10.670 olguda da hastalığa bağlı ölüm bildirilmiştir $(2,3)$. Lenfoblastik lösemi ise daha çok pediatrik yaş grubunda görülen ve lenfoblastlardan gelişen lösemi tipidir. B-ALL'lerin \%75'i 6 yaş altında karşımıza çıkar (1).

Lösemi ABD'de dokuzuncu en sık görülen malignite olup, maligniteye bağlı ölümlerde ise altıncı sıradadır (4). 100.000 popülasyonda, insidansı 13,8 olgu, mortalite hızı ise 6,7 olgudur (5). Lösemi tanısı için kemik iliğinde blast oranının \%20'nin üzerinde olması kriteri temeldir.

$\mathrm{Bu}$ çalışmada, Ege Üniversitesi Tıp Fakültesi (EÜTF) Hastanesi veri tabanına kayıtlı, 19922017 yıllarında akut lösemi tanısı alan 2.046 erişkin olgunun epidemiyolojik ve genel sağkalım analizlerinin yapılması, global sonuçlarla karşılaştırılarak değerlendirilmesi amaçlanmıştır.

\section{Gereç ve Yöntem}

EÜ Kanserle Savaş Araştırma ve Uygulama Merkezi (EÜKAM)'nin özel eğitimli ve sertifikalı kanser kayıt elemanları tarafından 1992-2017 yıllarında, EÜTF Hastanesi'nde 3125 lösemi tanısı alan hasta kaydı yapılmıştır. Çocuk hastalar (18 yaş altı) pediatri grubunda ele alınacağı için çalışmadan dışlanarak, 2046 erişkin lösemi hastası çalışmaya dahil edilmiştir.
$\mathrm{Bu}$ hastalar hastanemizde tanı ve/veya tedavi almışlardır. Sınıflandırmalarda ve sağkalım analizlerinde DSÖ ve Surveillance, Epidemiology, and End Results (SEER) verileri göz önüne alınarak gruplandırılmış; tümörün histolojik tipi, tanı yaşı, cinsiyet, tümör yerleşim yeri, tedavisi ve sağkalım analizleri açısından değerlendirilmiştir (1). Tümörün histolojik tipi açısından, AML, BALL/B-LBL, T-ALL/T-LBL, myeloid sarkom ve hücre dizisi belirsiz akut lösemiler olmak üzere gruplara ayrımıştır (1). CANREG 4 programı ile kaydedilen veriler SPSS (23.0 versiyonu) programına aktarılmıştır. İstatistiksel analizlerde Ki-kare, doğrusal modellemeler, student T-test, Mann Whitney-U, Fischer-exact test ve KaplanMeier sağkalım analizi yanı sıra Log-rank, cox regresyon analizi uygulanmış, $p<0,05$ değeri anlamlı kabul edilmiştir. Bu çalışmada, Ege Üniversitesi Tıbbi Araştırmalar Etik Kurulundan onay alınmıştır.

\section{Bulgular}

1992-2017 yıllarında Ege Üniversitesi Hastanesi veri tabanında kayıtlı 117.139 hastanın, 3.125'u akut lösemi tanısı almıştır. Akut lösemi tanısı alan olgular, hastanemiz veri tabanında kayıtlı tüm olguların yaklaşık \%2,67'sini oluşturmaktadır.

\section{Akut Lösemide Epidemiyolojik ve Histopatolojik Özellikler}

Akut lösemi tanısı alan toplam 3.125 hasta olup, 2.046'sı erişkin (18 yaş ve üzeri) olgulardır. Olguların \%58'i (n:1.186) erkek, \%42'si (n:860) kadın olup; ortalama tanı yaşı $50,62( \pm 18,14)$, medyan tanı yaşı ise 52 (aralık:18-94) idi. Histolojik alt tiplerine baktığımızda, $1.278(\% 62,5)$ olgu AML, $283(\% 13,8)$ olgu ALL, spesifiye edilemeyen, $197(\% 9,6)$ olgu B-ALL, $180(\% 8,8)$ olgu hücre dizisi belirsiz akut lösemi, $95(\% 4,6)$ olgu T-ALL ve $13(\% 0,6)$ olgu myeloid sarkom 
tanısı aldı. Olguların ayrıntılı histolojik tip dağılımları (Tablo-1)'de gösterilmiştir. Olguların 1.186'sı erkek, 860'ı kadın olup; erkek kadın oranı 1,4 idi (Tablo-1) (Şekil-1).

Olguların 1.960'ı $(\% 95,8)$ kemik iliği, 73'ü $(\% 3,6)$ nodal ve 13 'ü $(\% 0,6)$ ekstranodal yerleşimden tanı aldı. Nodal yerleşimden tanı alan olguların 39'u T-ALL, 21'i B-ALL, 12'si ALL, spesifiye edilemeyen ve biri myeloid sarkom idi. Ekstranodal yerleşimden tanı alan olguların dördü B-ALL, dördü ALL, spesifiye edilemeyen, ikisi T-ALL, ikisi myeloid sarkom ve biri indiferansiye lösemi idi. Topografi kodu dağılımlarına göre ekstranodal, C09.9 tonsil, C38,3 mediasten; nodal, C77.1 göğüs içi/intratorasik lenf düğümü, $\mathrm{C} 77.0$ baş, yüz, boyun lenf düğümü tutulumunun ön planda olduğu dikkatimizi çekti. Özellikle T-ALL'de intratorasik LN / mediasten yerleşimi ön planda idi. Histolojik tiplere göre ayrıntılı değerlendirme (Şekil-2)'de verilmiştir.

Olguların \%67,6'sı merkezimizde tedavi aldı. Tedavi ayrıntısına baktığımızda; 1.932 olgunun 1.235 'i $(\% 63,9)$ kemoterapi (KT) alır iken, 697'si $(\% 34,1)$ KT almadı. 48 olguya radyoterapi uygulandı. Olgularımızın sadece $\% 0,5$ 'ine cerrahi uygulandı, bu hastalarımızın büyük çoğunluğu myeloid sarkom olgularıydı. Ayrıca 1.949 olgunun 74'ü $(\% 3,8)$ immunoterapi aldı. İmmunoterapi alan olguların \%72,9'u AML grubunda idi.

\section{Akut Löseminin Yıllara ve Yaş Gruplarına Göre Dağılım Özellikleri}

Olguların yıllara göre dağılım özelliklerini incelediğimizde; sınıflandırılamayan ALL, olguları yıllara göre azalırken, diğer gruplarda yıllara göre lösemi tanısında artış dikkatimizi çekti (Şekil-3).

Tablo-1. Histolojik alt tip, cinsiyet ve yaş dağılımı.

\begin{tabular}{|c|c|c|c|c|c|}
\hline & Olgu sayısı & $\%$ & Erkek & Kadın & Ort. Yaş (std dev) \\
\hline B-ALL/B-LBL & 197 & 9,6 & 118 & 79 & $45,94( \pm 18,55)(18-86)$ \\
\hline T-ALL/B-LBL & 95 & 4,6 & 62 & 33 & $40,68( \pm 16,45)(18-85)$ \\
\hline ALL, NOS & 283 & 13,8 & 170 & 113 & $\mathbf{4 4 , 5 7}( \pm 19,25)(18-90)$ \\
\hline AML, NOS & 842 & 41,2 & 476 & 366 & $52,89( \pm 17,07)(18-94)$ \\
\hline AML, minimal differansiyasyonlu & 210 & 10,3 & 113 & 97 & $50,21( \pm 17,39)(18-89)$ \\
\hline AML, maturasyon göstermeyen & 6 & 0,3 & 6 & 0 & $54,83(21,34)(22-75)$ \\
\hline AML, maturasyon gösteren & 23 & 1,1 & 13 & 10 & $37,09( \pm 14,04)(19-67)$ \\
\hline Akut myelomonositik lösemi & 36 & 1,8 & 22 & 14 & $45,25( \pm 16,86)(19-77)$ \\
\hline $\begin{array}{l}\text { Akut monoblastik/monositik } \\
\text { lösemi }\end{array}$ & 22 & 1,1 & 11 & 11 & $50,82( \pm 18,28)(18-80)$ \\
\hline Pür eritroid lösemi & 12 & 0,6 & 4 & 8 & $52,75( \pm 23,41)(22-83)$ \\
\hline Akut megakaryoblastik lösemi & 11 & 0,5 & 7 & 4 & $45( \pm 20,02)(18-77)$ \\
\hline $\begin{array}{l}\text { Myelofibrozis ile karakterli akut } \\
\text { panmyelozis }\end{array}$ & 69 & 3,4 & 43 & 26 & $60,23( \pm 12,94)(20-80)$ \\
\hline $\begin{array}{l}\text { Tekrarlayan genetik anomaliler } \\
\text { ile karakterli AML }\end{array}$ & 47 & 2,3 & 22 & 25 & $49,85( \pm 17,82)(21-81)$ \\
\hline Myeloid sarkom & 13 & 0,6 & 11 & 2 & $\mathbf{4 1 , 4 6}( \pm 17,70)(19-73)$ \\
\hline Mikst fenotipte akut lösemi & 3 & 0,1 & 2 & 1 & $50,67( \pm 21,22)(36-75)$ \\
\hline Akut indiferansiye lösemi & 177 & 8,7 & 106 & 71 & $60,56( \pm 15,75)(20-88)$ \\
\hline
\end{tabular}

Kısaltmalar: B-ALL: B lenfoblastik lösemi/lenfoma, T-ALL: $\mathrm{T}$ lenfoblastik lösemi/lenfoma, $A L L$, NOS: Lenfoblastik lösemi/lenfoma, sınıflandırılamayan, AML: Akut myeloid lösemi, NOS: sınıflandırılamayan. 


\section{Histolojik tiplere göre cinsiyet dağılımı}

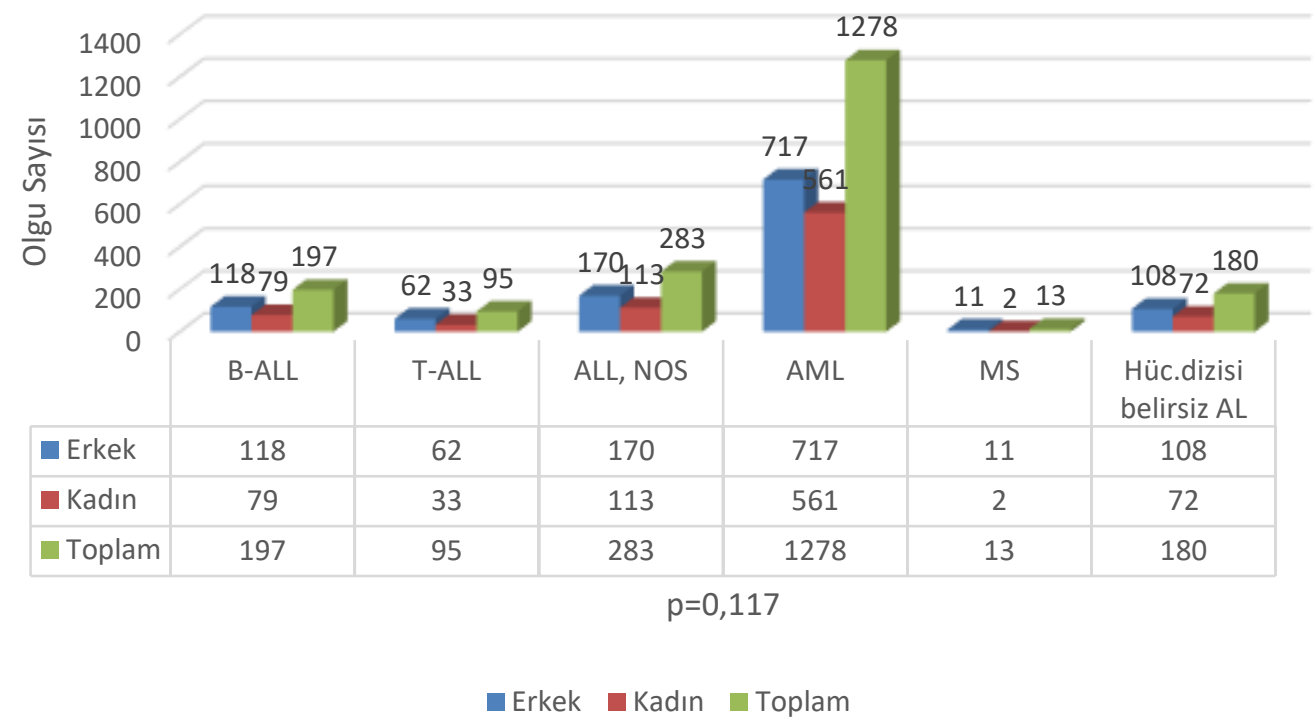

Şekil-1. Histolojik tiplere göre cinsiyet dağılımı.

Kısaltmalar: B-ALL: B lenfoblastik lösemi/lenfoma, T-ALL: T lenfoblastik lösemi/lenfoma, ALL, NOS: Lenfoblastik lösemi/lenfoma, sınıflandırılamayan, AML: Akut myeloid lösemi, MS: Myeloid sarkom, Hüc. dizisi belirsiz AL: Hücre dizisi belirsiz akut lösemi.

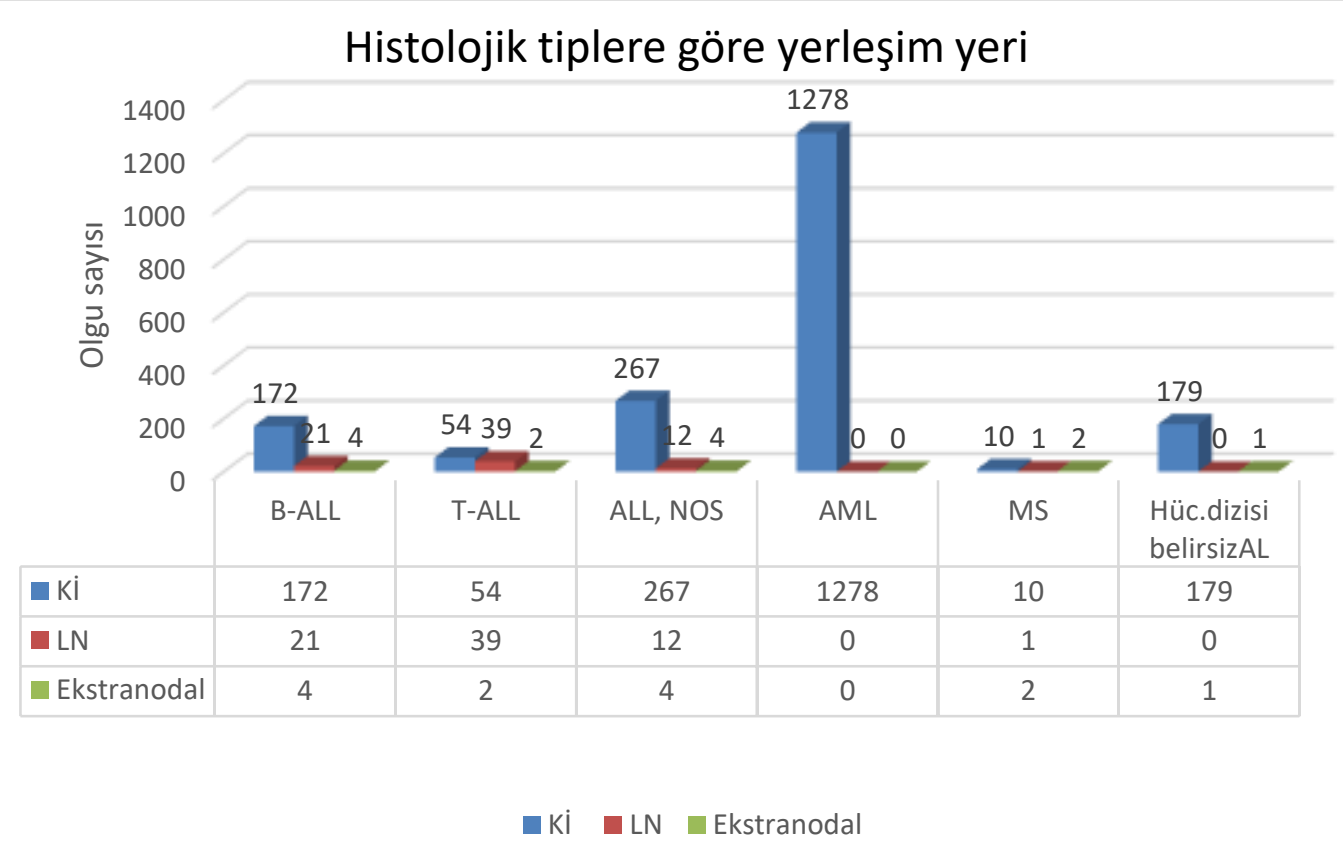

Şekil-2. Histolojik tiplere göre yerleşim yeri dağılımı.

Kısaltmalar: B-ALL: B lenfoblastik lösemi/lenfoma, T-ALL: T lenfoblastik lösemi/lenfoma, ALL, NOS: Lenfoblastik lösemi/lenfoma, sınıflandırılamayan, AML: Akut myeloid lösemi, MS: Myeloid sarkom, Hüc. dizisi belirsiz AL: Hücre dizisi belirsiz akut lösemi, Kí: Kemik iliği, LN: Lenf nodülü. 


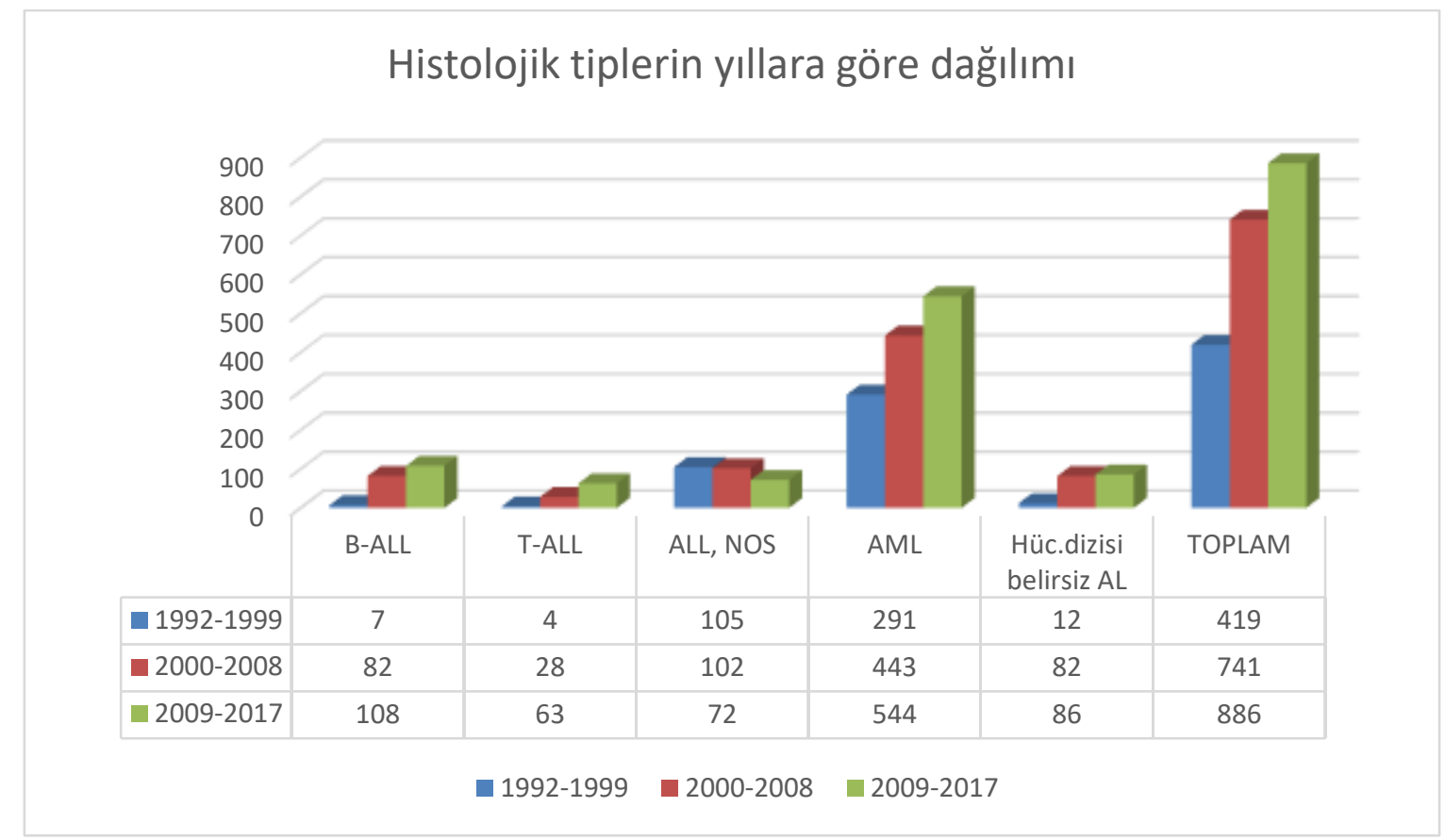

Şekil-3. Histolojik tiplerin yıllara göre dağılım grafiği.

Kısaltmalar: B-ALL: B lenfoblastik lösemi/lenfoma, T-ALL: T lenfoblastik lösemi/lenfoma, ALL, NOS: Lenfoblastik lösemi/lenfoma, sınıflandırılamayan, AML: Akut myeloid lösemi, Hüc. dizisi belirsiz AL: Hücre dizisi belirsiz akut lösemi.

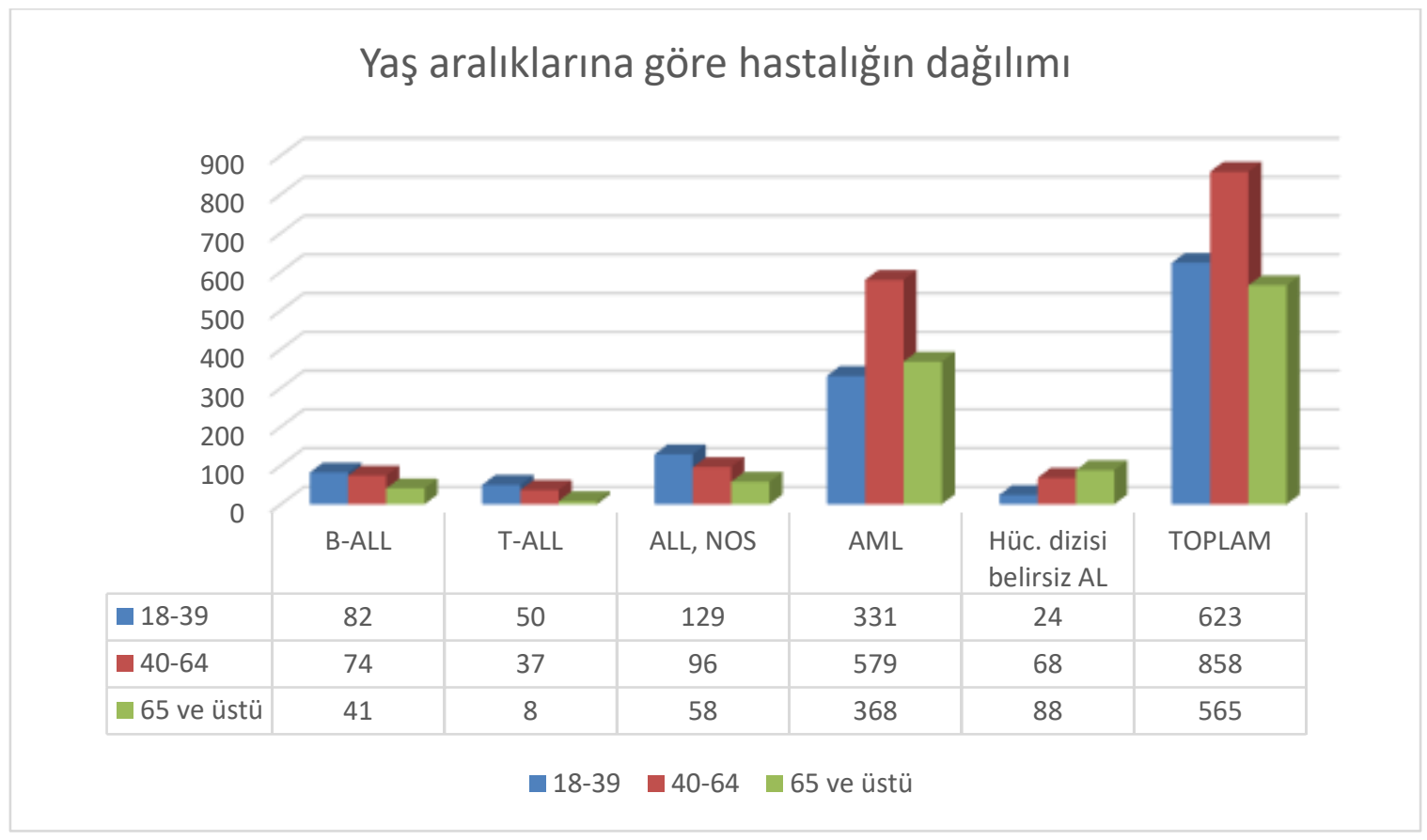

Şekil-4. Yaş aralıklarına göre hastalığın dağııım grafiği.

Kısaltmalar: B-ALL: B lenfoblastik lösemi/lenfoma, T-ALL: T lenfoblastik lösemi/lenfoma, ALL, NOS: Lenfoblastik lösemi/lenfoma, sınıflandırılamayan, AML: Akut myeloid lösemi, Hüc. dizisi belirsiz AL: Hücre dizisi belirsiz akut lösemi. 
Çocukluk yaş grubunda daha sık karşımıza çıkan ALL olgularında yaş arttıkça görülme oranlarının azaldığı, hücre dizisi belirsiz akut lösemi olgularında ise yaş arttıkça görülme oranlarının da arttığı saptandı (Şekil-4). AML ve tüm lösemi olguları ise en çok 40-64 yaş aralığında yer almaktaydı (Şekil-4).

\section{Akut Lösemide Sağkalım Özellikleri}

Sağkalım analizlerine baktığımızda olguların 747'si $(\% 36,5)$ sağ, 1.299'u $(\% 63,5)$ ölü idi. Histolojik tiplere göre son durum bilgileri (Tablo-

2) ve (Şekil-5)'te değerlendirildi $(p=0,006)$.

Tablo-2. Histolojik alt tip-son durum ve sağkalım.

\begin{tabular}{|c|c|c|c|c|c|}
\hline & $\begin{array}{l}\text { Olgu } \\
\text { sayısı }\end{array}$ & $\%$ & Sağ & Ölü & Ort. sağkalım süresi (gün) \\
\hline B-ALL/B-LBL & 197 & 9,6 & 67 & 130 & $\begin{array}{l}\text { 1040, } 14( \pm 1427,84) \\
(0-6836)\end{array}$ \\
\hline T-ALL/B-LBL & 95 & 4,6 & 34 & 61 & $\begin{array}{l}1093,71( \pm 1214,93) \\
(8-5984)\end{array}$ \\
\hline ALL, NOS & 283 & 13,8 & 134 & 149 & $\begin{array}{l}\mathbf{1 2 3 1 , 8}( \pm 1920,64) \\
(0-9160)\end{array}$ \\
\hline AML, NOS & 842 & 41,2 & 296 & 546 & $\begin{array}{l}719,68( \pm 1502,36) \\
(0-9556)\end{array}$ \\
\hline AML, minimal differansiyasyonlu & 210 & 10,3 & 67 & 143 & $\begin{array}{l}\mathbf{8 1 4 , 8 0}( \pm 1486,86) \\
(0-6674)\end{array}$ \\
\hline AML, maturasyon göstermeyen & 6 & 0,3 & 0 & 6 & $\begin{array}{l}\mathbf{1 2 1 , 3 3}( \pm 145,81) \\
(10-377)\end{array}$ \\
\hline AML, maturasyon gösteren & 23 & 1,1 & 14 & 9 & $\begin{array}{l}2857( \pm 1887,29) \\
(39-5279)\end{array}$ \\
\hline Akut myelomonositik lösemi & 36 & 1,8 & 16 & 20 & $\begin{array}{l}1470,75( \pm 2245,44) \\
(1-7202)\end{array}$ \\
\hline Akut monoblastik/monositik lösemi & 22 & 1,1 & 8 & 14 & $\begin{array}{l}1625,86( \pm 2036,83) \\
(3-5889)\end{array}$ \\
\hline Pür eritroid lösemi & 12 & 0,6 & 3 & 9 & $1186,92( \pm 1733,25)(26-4793)$ \\
\hline Akut megakaryoblastik lösemi & 11 & 0,5 & 4 & 7 & $980,82( \pm 2189,69)(47-7447)$ \\
\hline $\begin{array}{l}\text { Myelofibrozis ile karakterli akut } \\
\text { panmyelozis }\end{array}$ & 69 & 3,4 & 24 & 45 & $1870,51( \pm 1340,28)(45-6012)$ \\
\hline $\begin{array}{l}\text { Tekrarlayan genetik anomaliler ile } \\
\text { karakterli AML }\end{array}$ & 47 & 2,3 & 19 & 28 & $\begin{array}{l}1675,85( \pm 1892,98) \\
(1-5697)\end{array}$ \\
\hline Myeloid sarkom & 13 & 0,6 & 4 & 9 & $\begin{array}{l}1227,85( \pm 1092,97) \\
(56-3408)\end{array}$ \\
\hline Mikst fenotipte akut lösemi & 3 & 0,1 & 0 & 3 & $\begin{array}{l}309,33( \pm 416,61) \\
(52-790)\end{array}$ \\
\hline Akut indiferansiye lösemi & 177 & 8,7 & 57 & 120 & $\begin{array}{l}1271,29(1634,22) \\
(0-9230)\end{array}$ \\
\hline
\end{tabular}

Kısaltmalar: B-ALL: B lenfoblastik lösemi/lenfoma, T-ALL: $\mathrm{T}$ lenfoblastik lösemi/lenfoma, ALL, NOS: Lenfoblastik lösemi/lenfoma, sınıflandırılamayan, AML: Akut myeloid lösemi, NOS: sınıflandırılamayan. 


\section{Histolojik tiplere göre son durum bilgileri}

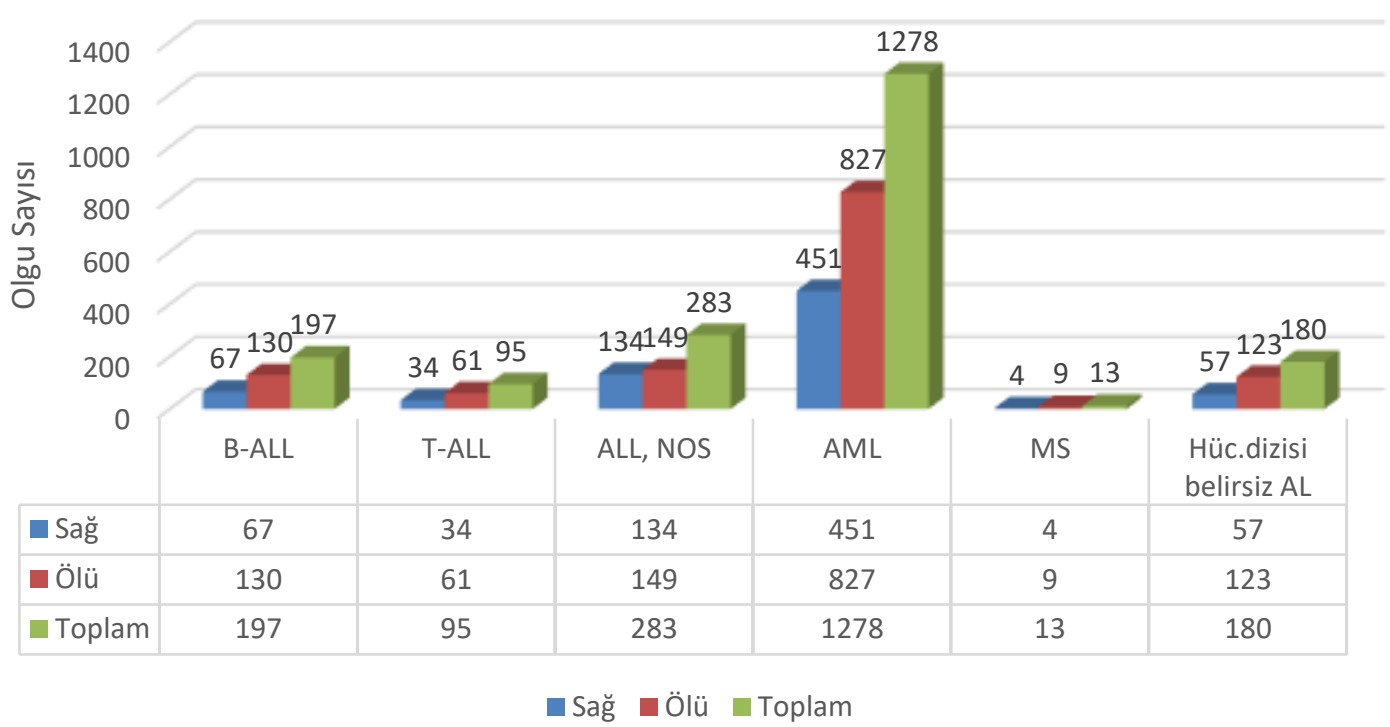

Şekil-5. Histolojik tiplere göre son durum bilgileri.

KIsaltmalar: B-ALL: B lenfoblastik lösemi/lenfoma, T-ALL: T lenfoblastik lösemi/lenfoma, ALL, NOS: Lenfoblastik lösemi/lenfoma, sınıflandırılamayan, AML: Akut myeloid lösemi, MS: Myeloid sarkom, Hüc. dizisi belirsiz AL: Hücre dizisi belirsiz akut lösemi.

Tablo-3. Sağ kalım verilerinin ayrıntılı değerlendirilmesi.

\begin{tabular}{|c|c|c|c|c|c|c|}
\hline & $\begin{array}{l}\text { 1-yıllık } \\
\text { sağkalım }\end{array}$ & $\begin{array}{l}\text { 5-yıllık } \\
\text { sağkalım }\end{array}$ & $\begin{array}{l}\text { 10-yıllık } \\
\text { sağkalım }\end{array}$ & $\begin{array}{l}\text { 15-yıllık } \\
\text { sağkalım }\end{array}$ & $\begin{array}{l}\text { 20-yıllık } \\
\text { sağkalım }\end{array}$ & \\
\hline B-ALL & $\% 56$ & $\% 32$ & $\% 23$ & $\% 23$ & & $p<0,0001$ \\
\hline T-ALL & $\% 66$ & $\% 32$ & $\% 30$ & $\% 30$ & & \\
\hline ALL, NOS & $\% 69$ & $\% 37$ & $\% 30$ & $\% 30$ & $\% 25$ & \\
\hline AML & $\% 51$ & $\% 26$ & $\% 22$ & $\% 20$ & $\% 18$ & \\
\hline MS & $\% 69$ & $\% 37$ & & & & \\
\hline Hücre dizisi belirsiz AL & $\% 62$ & $\% 33$ & $\% 23$ & $\% 23$ & $\% 17$ & \\
\hline Erkek & $\% 55$ & $\% 28$ & $\% 23$ & $\% 21$ & $\% 19$ & $\mathrm{p}=0,36$ \\
\hline Kadın & $\% 56$ & $\% 30$ & $\% 24$ & $\% 24$ & $\% 18$ & \\
\hline Ki & $\% 55$ & $\% 28$ & $\% 22$ & $\% 22$ & $\% 19$ & $\mathrm{p}=0,01$ \\
\hline LN & $\% 70$ & $\% 38$ & $\% 38$ & $\% 38$ & $\% 19$ & \\
\hline Ekstranodal & $\% 74$ & $\% 52$ & $\% 52$ & $\% 52$ & $\% 52$ & \\
\hline Tedavi - & $\% 47$ & $\% 27$ & $\% 19$ & $\% 17$ & $\% 15$ & $\mathrm{p}<0,0001$ \\
\hline Tedavi + & $\% 59$ & $\% 29$ & $\% 25$ & $\% 25$ & $\% 21$ & \\
\hline KT - & $\% 50$ & $\% 27$ & $\% 19$ & $\% 17$ & $\% 16$ & $p=0,001$ \\
\hline $\mathrm{KT}+$ & $\% 59$ & $\% 30$ & $\% 26$ & $\% 25$ & $\% 21$ & \\
\hline İmmunoterapi- & $\% 54$ & $\% 28$ & $\% 22$ & $\% 22$ & $\% 18$ & $p<0,0001$ \\
\hline İmmunoterapi+ & $\% 78$ & $\% 44$ & $\% 40$ & $\% 40$ & & \\
\hline $18-39$ yaş & $\% 69$ & $\% 41$ & $\% 39$ & $\% 39$ & $\% 35$ & $p<0,0001$ \\
\hline $40-64$ yaş & $\% 55$ & $\% 31$ & $\% 24$ & $\% 23$ & $\% 17$ & \\
\hline 65 ve üstü & $\% 41$ & $\% 13$ & $\% 6$ & & & \\
\hline
\end{tabular}

Kısaltmalar: B-ALL: B lenfoblastik lösemi/lenfoma, T-ALL: T lenfoblastik lösemi/lenfoma, ALL, NOS: Lenfoblastik lösemi/lenfoma, sınıflandırılamayan, AML: Akut myeloid lösemi, MS: Myeloid sarkom, Hücre dizisi belirsiz AL: Hücre dizisi belirsiz akut lösemi, Ki: Kemik iliği, LN: Lenf nodülü, "“-" almayan, "+": alan. 
Tüm akut lösemi olgularının 1 yıllık sağkalımı $\% 55,7,2$ yılllık sağkalım \%42, 5 yıllık sağkalım $\% 29,10$ yıllık sağkalım \%23, 15 yıllık sağkalım \%22, 20 yıllık sağkalım \%19, 25 yıllık sağkalım \%15'tir. Medyan sağkalım 17 ay (\%95 güven aralığı:14,6-18,7) dır. Erkeklerde sağkalım \%36,3 iken, kadınlarda \%36,9 dolayında bulundu. Lokalizasyonlara göre sağkalım analizine bakıldığında, lösemik prezentasyon gösteren olguların \%36'sı, lenf nodülünden tanı alan olguların \%45,2'si, ekstranodal yerleşimden tanı alan olguların $\% 61,5$ 'i sağ idi. Tedavi alanlarda sağkalım \%39,4 iken, tedavi almayanlarda \%27 idi. KT alanlarda sağkalım \%40,4 iken, almayanlarda \%27,5 dolayında saptandı. İmmunoterapi alanlarda sağkalım \%45,9 iken, almayanlarda \%35,5 olarak saptandı. Yaş aralıklarına göre sağkalım 18-39 yaş grubunda $\% 52,3,40-64$ yaş grubunda $\% 35,3,65$ yaş ve üstü grupta \%20,9 olarak bulundu. Sağkalım verilerinin ayrıntılı olarak değerlendirilmesi (Tablo-3)'de verilmiştir.

Beklenildiği gibi tedavi alanlarda sağkalım almayanlara göre daha uzun idi ve istatistiksel olarak da anlamlı bulundu $(p<0,0001)$.

Ayrıca yaş aralıklarına göre sağkalım analizine bakıldığında, 18-39 yaş aralığında sağkalım en uzun iken, 65 ve üstü grupta sağkalım en kısa idi ve aradaki fark istatistiksel olarak da anlamlı saptandı $(p<0,0001)$ (Şekil-6).

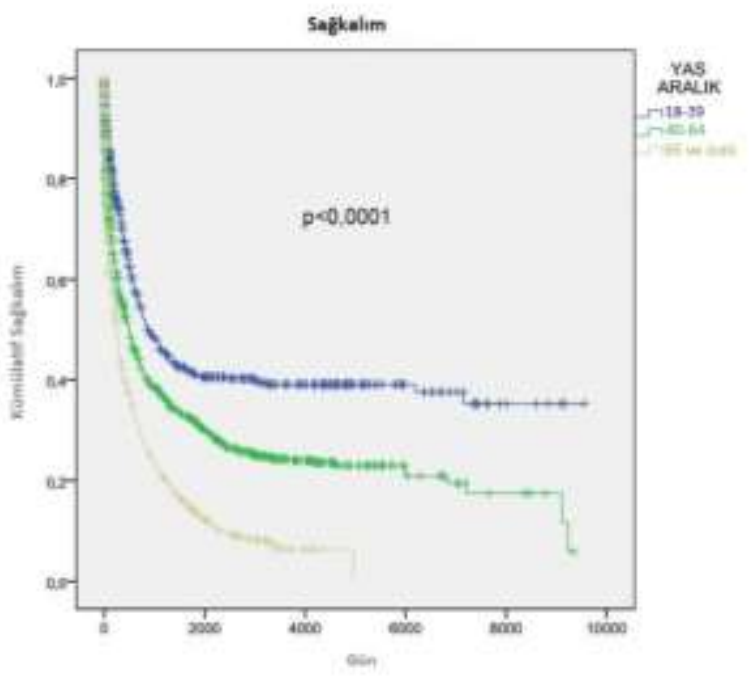

Şekil-6. Yaş aralıklarına göre sağkalım grafiği.

\section{Tartışma}

GLOBOCAN 2018 verilerine göre lösemi, tüm malignitelerin \%2,4'ünü oluşturmaktadır (6), bizim serimizde ise bu oran \%2,67'dir.

Daha çok ileri yaşta karşımıza çıkan akut myeloid lösemi, myeloid kök hücrelerden gelişen ve erişkinlerde en sık görülen lösemi tipidir (7). Bizim çalışmamızda da en sık görülen lösemi tipi olup, olguların \%62,5'ini oluşturmaktadır. 2017 Dünya Sağlık Örgütü kitabında AML; tekrarlayan genetik anomaliler ile karakterli AML, myelodisplazi ilişkili değişiklikler ile karakterli AML, tedavi ilişkili myeloid neoplaziler, AML spesifiye edilemeyen, myeloid sarkom ve Down sendromu ilişkili myeloproliferatif neoplazmlar olmak üzere gruplara ayrılır. Ayrıca minimal differansiyasyon gösteren AML (FAB M0), maturasyon göstermeyen AML (FAB M1), maturasyon gösteren $A M L$ ( $F A B M 2)$, akut myelomonositik lösemi (FAB M4), akut monoblastik/monositik lösemi (FAB M5), pür eritroid lösemi (FAB M6), akut megakaryoblastik lösemi (FAB M7), akut bazofilik lösemi ve myelofibrozis ile karakterli akut panmyelozis ise spesifiye edilemeyen AML alt gruplarıdır (1). PML-RARA ile karakterli akut promyelositik lösemi (FAB M3), $t(15 ; 17)(q 22 ; q 12)$ gösterir ve tekrarlayan genetik anomaliler ile karakterli AML grubu içerisinde yer alır (1).

AML erkeklerde daha sık görülmektedir (8). Bizim serimizde de erkek üstünlüğü dikkat çekmektedir. AML medyan tanı yaşı 67'dir (3,7). Bizim AML olgularımızda medyan tanı yaşı 52 olarak saptandı. Yaşla birlikte AML görülme oranı artar. Çalışmalarda gösterilmiş ki 80-84 yaş aralığında en sık görülürken, 85 ve üstü grupta görülme oranı çok hafif azalma göstermektedir (7). Bizim serimizde AML en çok 40-64 yaş aralığında olup, 65 yaş ve üstü grupta bir miktar azalma göstermektedir.

2017 Dünya Sağlık Örgütü kitabında B-ALL/LBL; spesifiye edilemeyen B-ALL ve tekrarlayan genetik anomaliler ile karakterli B-ALL den oluşur (1). Dünya'da yıllık insidansı, her 100.000 popülasyonda $1-4,75$ olgudur. ABD'de yılda yaklaşık 6.000 yeni olgu bildirilmektedir (1). Bizim serimizde de ikinci en sık görülen lösemi tipi olup, olguların \%9,6'sını oluşturmaktadır. Yaklaşık \%80-85'i prekürsör B hücrelerinden gelişir. TALL/LBL, çocukluk çağı ALL olgularının\%15'ini oluşturur. Adolesan ve erkeklerde daha sık karşımıza çıkar. Ayrıca erişkin ALL olgularının 
yaklaşık \%25'ini oluşturur. Bizim çalışmamızda B-ALL \%67,5, T-ALL ise $\% 32,5$ dolayında saptandı. T-LBL ise tüm LBL olgularının yaklaşık \%85-90'ını oluşturur. Adolesan erkeklerde daha sık görülmekle birlikte, her yaşta karşımıza çıkabilir (1). Bizim çalışmamızda erkek:kadın oranı 1,9 olup, ortalama tanı yaşı 40,68 olarak bulundu.

2017 Dünya Sağıık Örgütü sınıflandırmasında hücre dizisi belirsiz akut lösemiler; akut indiferansiye lösemi ve mikst fenotipte akut lösemiden oluşmaktadır (1). Bu grup tek diziye farklılaşma yönünde bulgu içermez. Akut indiferansiye lösemide, dizi spesifik antijen ekspresyonu saptanmaz iken, mikst fenotip akut lösemide ise birden fazla diziye ait antijen ekspresyonu saptanır. Hücre dizisi belirsiz akut lösemiler tüm akut lösemilerin \%4'ten azını oluşturur (1), bizim serimizde bu oran literatürden daha yüksek olarak $\% 8,8$ olarak bulunmuştur. Akut indiferansiye lösemi, mikst fenotip akut lösemiye göre daha sık görülmektedir (9). Bizim olgularımızda da mikst fenotip akut lösemi, çok daha nadir olarak karşımıza çıkmaktadır. Akut indiferansiye lösemide medyan tanı yaşı en yüksek olup, 74 olarak bildirilmiştir (10). Bizim olgularımızda içerisinde de medyan tanı yaşı en yüksek grup olup, 64 olarak bulunmuştur. Ayrıca 1.888 akut indiferansiye lösemi olgularının değerlendirildiği bir çalışmada insidansı yıllar içerisinde belirgin azalma göstermektedir (10). Bizim çalışmamızda da hücre dizisi belirsiz akut lösemilerin görülme oranı 2009-2017 yıllarında bir önceki döneme göre azalma göstermektedir.

Akut lösemiler, sıklıkla kemik iliği ve periferik kanda görülmekle birlikte, ekstramedüller lokalizasyonda da karşımıza çıkabilir. BALL/LBL'de kemik iliği tutulumu ön plandadır, sıklıkla periferik kan tutulumu eşlik eder, bazı olgularda nodal ve santral sinir sistemi öncelikli olmak üzere ekstranodal tutulum görülebilir. Ancak T-ALL kemik iliği tutulumu ile karakterlidir ve alösemik tutulum B-ALL'ye kıyasla çok nadirdir; T-LBL'da mediastinal (timik) tutulum sıktır. T-LBL'de nodal tutulum yanı sıra deri, tonsil, karaciğer, dalak, santral sinir sistemi ve testis gibi ekstranodal tutulumda görülebilir; ancak, nodal ya da mediastinal tutulum olmaksızın izole ekstranodal tutulum pek beklenmez. Bizim serimizde de özellikle intratorasik $\mathrm{LN} /$ mediasten yerleşimi ön planda idi.

Akut promyelositik lösemi, artmış dissemine intravasküler koagulasyon ve fibrinoliz riski nedeniyle hayati tehlike içerir; bir an önce tedaviye başlanması gerekir. Tretinoin ve arsenik trioksid kombinasyon tedavilerine çok iyi yanıt verir. AML subtipi ve içerdiği genetik anomalilere bağlı olarak prognozları değişkenlik gösterir. BALL/LBL'de pediatrik grupta prognoz çok iyidir (1). Komplet remisyon oranları pediatrik grupta \%95'in üzerinde iken, erişkinlerde \%60-85 dolayındadır. Çocularda kür oranı, $\% 80$ dolayında iken; erişkinlerde \%50'nin altındadır. Tanı anında santral sinir sistemi tutulumu kötü prognoz ile ilişkilidir ve farklı tedavi protokolleri gerektirir. Ayrıca yüksek lökosit sayısına bağıı ilk tedaviye geç yanıt ve tedavi sonrası minimal rezidüel hastalık kötü prognostik faktörler arasında sayılabilir. T-ALL/LBL'de prognoz, lenfomalarda olduğu gibi yaş, evre ve LDH düzeyi ile ilişkilidir. Çocuklarda B-ALL'ye göre daha kötü iken, erişkinlerde B-ALL'ye göre daha iyi seyreder. Erişkin yaş grubunu kapsayan bizim olgularımızda da T-ALL, B-ALL'ye göre daha uzun sağkalım özellikleri göstermektedir. Ayrıca B-ALL ile kıyaslandığında indüksiyon tedavisine yetersiz yanıt gösterir, erken relaps yanı sıra izole santral sinir sistemi relapsı da daha sık görülür. Hem erişkin hem de pediatrik grupta AML, ALL'ye göre daha kısa sağkalım göstermektedir (10). Bizim serimizde de AML daha kötü prognostik özellikler gösterirken, ALL'de sağkalım daha uzun saptanmıştır.

AML de Appelbaum (11), Juliusson (12) ve ark tarafından yapılan çalışmalarda, yaş aralığı arttıkça genel sağkalımın azaldığı gösterilmiştir $(4,7)$. Bizim olgularımızda da yaş arttıkça sağkalımın kısaldığı dikkatimizi çekti $(p<0,0001)$.

Özellikle gelişmiş ülkelerde yıllar içerisinde lösemi görülme oranlarında artış dikkat çekmektedir. Lösemiye ait çok geniş bir serinin değerlendirildiği çalışmamız, toplumumuza ait epidemiyolojik ve sağkalım özelliklerinin anlaşılabilmesi, global verilerle karşılaştırılarak tarama ve tedavi protokollerinin oluşturulabilmesi ve ulusal hastalık stratejisi belirlenebilmesi açısından önem taşımaktadır.

\section{Sonuç}

Sonuç olarak, EUKAM tarafından kaydedilmiş, 25 yıllık veri analiz bulgularımıza göre lösemi, erkeklerde kadınlara göre daha sık karşımıza çıkmaktadır. Erişkinlerde AML en sık görülen lösemi alt tipidir. Global veriler ile uyumlu olarak yıllara göre lösemi tanısında artış bizim serimizde de öne çıkmaktadır. Çocukluk yaş grubunda daha sık olan ALL olgularında yaş artıkça 
görülme oranlarının azaldığı, hücre dizisi belirsiz akut lösemi olgularında ise yaş arttıkça görülme oranlarının da arttığı saptanmıştır. AML ve tüm lösemi olguları ise en çok 40-64 yaş aralığında yer almaktadır. Cinsiyet ve sağkalım arasında bir fark saptanmaz iken, lösemik prezentasyon gösterenlerde, tedavi almayan olgularda ve yaş artıkça sağkalım daha kısa bulunmuş ve istatistiksel olarak da anlamlı saptanmıştır. Prognozda, histolojik tip, yaş ve tedavi bizim çalışmamızda da öne çıkan önemli parametrelerdendir.
Çıkar çatışması: Yazarlar çıkar çatışması beyan etmemişlerdir.

Teşekkür: Bu çalışma 25 yıllık uzun bir dönemi kapsamaktadır. Bu süreçte emekleri geçen tüm Ege Üniversitesi Hematoloji Bilim Dalı öğretim üyeleri ve olguların tanı sürecinde eğitimimize sonsuz katkılarından dolayı hocamız Prof. Dr. Saliha Soydan'a, EÜKAM yetkilisi Ömer Karaca başta olmak üzere tüm kanser kayıt elemanlarına teşekkür ederiz.

\section{Kaynaklar}

1. Swerdlow SH, Campo E, Harris NL, et al. WHO classification of tumours of haematopoietic and lymphoid tissues, 4th edition (IARC WHO Classification of Tumours, Volume 2). International. agency for research on Cancer (IARC). Lyon, 2017:128-189. KITAP ATIFI EKSIK, BÖLÜM BAŞLIĞI VE BÖLÜM YAZARLARI YOK.

2. Siegel RL, Miller KD, Jemal A. Cancer Statistics , 2018. CA Cancer J Clin 2018;68(1):7-30.

3. Zeidan AM, Podoltsev NA, Wang $X$, et al. Temporal patterns and predictors of receiving no active treatment among older patients with acute myeloid leukemia in the United States: A population-level analysis. Cancer 2019;125(23):4241-51.

4. Utuama O, Mukhtar F, Pham YTH, et al. Racial/ethnic, age and sex disparities in leukemia survival among adults in the United States during 1973-2014 period. PLoS One 2019;14(8):1-12.

5. Noone A, Howlader N, Krapcho M, et al. SEER Cancer Statistics Review, 1975-2015, National Cancer Institute. Natl Cancer Inst 2018. Available from: www.seer.cancer.gov/archive/csr/1975_2015/

6. Bray F, Ferlay J, Soerjomataram I, Siegel RL, Torre LA, Jemal A. Global Cancer Statistics 2018: GLOBOCAN Estimates of Incidence and Mortality Worldwide for 36 Cancers in 185 Countries. CA Cancer J Clin 2018;68(6):394-424.

7. Podoltsev NA, Stahl M, Zeidan AM, Gore SD. Selecting initial treatment of acute myeloid leukaemia in older adults. Blood Rev 2017;31(2):43-62.

8. Takaoka K, Koya J, Yoshimi A, et al. Nationwide epidemiological survey of familial myelodysplastic syndromes/acute myeloid leukemia in Japan: a multicenter retrospective study. Leuk Lymphoma 2020;61(7):1-7.

9. Murthy GSG, Dhakal I, Lee JY, Mehta P. Acute Leukemia of Ambiguous Lineage in Elderly Patients: A SEERMedicare Database Analysis. Clin Lymphoma, Myeloma Leuk 2017;17(2):100-7.

10. Qasrawi A, Gomes V, Chacko CA, et al. Acute undifferentiated leukemia: data on incidence and outcomes from a large population-based database. Leuk Res 2020;89(1):106301. doi: https://doi.org/10.1016/j.leukres.2020.106301

11. Appelbaum FR, Gundacker H, Head HR, et al. Age and acute myeloid leukemiak. Blood. 2006;107 (9): $3481-5$.

12. Juliusson $G$, Antunovic $P$, Derolf $A$, et al. Age and acute myeloid leukemia: Real world data on decision to treat and outcomes from the Swedish Acute Leukemia Registry. Blood. 2009;113(18):4179-87. 